Zeszyty Naukowe Szkoły Głównej Gospodarstwa Wiejskiego w Warszawie

Problemy Rolnictwa Światowego tom 18 (XXXIII), zeszyt 3, 2018: 451-462

DOI: 10.22630/PRS.2018.18.4.133

Aneta Suchoń $^{1}$

Uniwersytet im. Adama Mickiewicza w Poznaniu

\title{
Spółdzielczość rolnicza we Francji i Niemczech - wybrane zagadnienia prawne i ekonomiczne
}

\section{Agricultural Cooperatives in France and Germany - Selected Legal and Economic Issues}

\begin{abstract}
Synopsis. Francja i Niemcy są przykładami państw, w których rolnictwo jest istotnym działem gospodarki, występuje duża liczba gospodarstw rolnych, a ruch spółdzielczy jest bardzo popularny. W Unii Europejskiej funkcjonuje ponad 22 tys. spółdzielni rolniczych. W ramach rozważań zaprezentowano dane statystyczne i regulacje prawne dotyczące spółdzielni rolniczych we Francji i Niemczech, w szczególności francuski Code Rural oraz niemiecką ustawa Genossenschaftsgesetz. W podsumowaniu autorka stwierdziła, że polski prawodawca, tworząc nowy prawny model spółdzielczości, powinien bezsprzecznie skorzystać z doświadczeń i niektórych rozwiązań prawnych występujących w Niemczech i Francji, m.in. w zakresie wprowadzenia szerokiej definicji spółdzielni rolniczych, uproszczeń w zakresie zakładania i funkcjonowania tych podmiotów, instrumentów finansowych, w tym podatkowych, łączenia spółdzielni z innymi podmiotami spółdzielczymi czy spółkami kapitałowymi.
\end{abstract}

Słowa kluczowe: spółdzielnie rolnicze, rolnictwo, gospodarstwo rolne, spółdzielnie we Francji i Niemczech

\begin{abstract}
France and Germany are examples of countries where agriculture is an important part of the economy, there is a large number of farms and the cooperative movement is very popular. In the European Union there are over 22 thousand agricultural cooperatives. The article presents statistical data and legal regulations concerning agricultural cooperatives in France and Germany, in particular, the French Code Rural and the German Genossenschaftsgesetz. In conclusion the author states that the Polish legislature, creating a new model of cooperative law, should unquestionably draw on the experience and some legal solutions implemented in Germany and France, and in particular introduce a broad definition of agricultural cooperatives, a simplified procedure of their formation and functioning, financial instruments, including tax, and rules on merging cooperatives with other cooperative entities or companies.
\end{abstract}

Key words: agricultural cooperatives, agriculture, agricultural holding, cooperatives in France and Germany

JEL Classification: P13, Q13, K15, K22, N50,

\section{Wprowadzenie}

Spółdzielczość rolnicza ma długą historię i duże znaczenie praktyczne w większości krajów Unii Europejskiej. Według danych statystycznych funkcjonuje tam około 22 tys. spółdzielni rolniczych, a ich całkowity obrót przekracza 347 mld euro. Mają więcej niż

${ }^{1}$ dr hab. Aneta Suchoń, Katedra Prawa Rolnego, Wydział Prawa i Administracji UAM, ul. Św. Marcin 90, 61-809 Poznań, e-mail: suchon@amu.edu.pl; https://orcid.org/0000-0002-5410-7853 
$50 \%$ udziału $\mathrm{w}$ dostawach środków do produkcji rolniczej, a w skupie, przetwórstwie i marketingu produktów rolnych ponad $60 \%(\text { COGECA, 2014 })^{2}$. W niektórych państwach europejskich to właśnie dzięki rozszerzaniu przedmiotu działalności spółdzielni i dostosowaniu go do potrzeb rolnictwa oraz wymogów Wspólnej Polityki Rolnej, a także rozbudowanej strukturze, dbającej o rozwój spółdzielni, podmioty spółdzielcze są w dobrej kondycji finansowej iw dużym stopniu wspierają gospodarstwa rolne spółdzielców (COGECA, 2014; Suchoń, 2016). Odnotować należy także spółdzielnie zajmujące się prowadzeniem działalności rolniczej wytwórczej, np. Niemcy, Polska, Słowacja.

Francja i Niemcy są przykładami państw, w których ruch spółdzielczy jest bardzo popularny, a jego początki sięgają XIX w. Jednocześnie spółdzielnie są niezmiernie ważnym elementem gospodarki tych krajów, przyczyniając się do rozwoju obszarów wiejskich i rozwiązywania występujących tam problemów. Prowadzą działalność w zakresie m.in. zaopatrzenia, czyli nabywania dóbr potrzebnych do produkcji rolnej prowadzonej przez jej członków, usług agrotechnicznych, przechowania i wspólnej sprzedaży produktów rolnych, przetwórstwa (COGECA, 2014).

Wybór Francji i Niemiec nie jest przypadkowy. Są to dwa państwa w których rolnictwo jest ważną gałęzią gospodarki (według opracowania COGECA w Niemczech wkład rolnictwa w gospodarkę w 2014 r. wynosił ponad 54 mld euro, a we Francji ponad 77 mld euro), działalność rolniczą prowadzi duża liczba producentów rolnych (w Niemczech w 2010 r. było ponad 299 tys. gospodarstw rolnych, a we Francji ponad 489 tys.) oraz funkcjonuje znaczna liczba spółdzielni rolniczych i spółdzielców (wNiemczech działa 2400 takich podmiotów, zrzeszając 1440600 członków i generując obrót w wysokości ponad 67,502 mld euro, a we Francji 2800 spółdzielni rolniczych, z 858 tys. członków obrotem 84,350 mld euro) (COGECA, 2014).

Celami artykułu są: po pierwsze przybliżenie polskiemu czytelnikowi prawnych i ekonomicznych zagadnień dotyczących funkcjonowania spółdzielni działających w rolnictwie we Francji i Niemczech, a po drugie próba wskazania występujących w tych krajach rozwiązań prawnych, które mogą zostać wykorzystane w Polsce podczas prac legislacyjnych dotyczących spółdzielni, szczególnie rolniczych.

Podstawową metodą badawczą jest - charakterystyczna dla pracy prawnika dogmatyczna analiza tekstów normatywnych. Badaniu poddane zostały przede wszystkim akty prawne dotyczące spółdzielczości we Francji i Niemczech. Rozważania typowo prawnicze poparte zostały danymi statystycznymi, rysem historycznym i informacjami praktycznymi.

\footnotetext{
${ }^{2}$ We Francji łącznie funkcjonowało w latach 2006-2009 ponad 21 tys. spółdzielni, we Włoszech - 41,5 tys., w Hiszpanii - 24 tys., Szwecji - 9,1 tys., w Polsce $-8,8$ tys. Poza UE: w Norwegii - 5,3 tys., na Ukrainie 5,1 tys. spółdzielni. Pod względem liczby członków spółdzielni pierwsze miejsce zajmuje Francja (23 mln członków), drugie Niemcy $(20,5 \mathrm{mln})$, trzecie Włochy $(13 \mathrm{mln})$, czwarte Wielka Brytania $(8,4 \mathrm{mln})$, piąte Polska (ok. $8 \mathrm{mln}$ ). Jeżeli chodzi o zatrudnienie w spółdzielniach, najwięcej osób pracuje w tym sektorze we Włoszech (1,1 mln pracowników), Francji (900 tys.) i w Niemczech (830 tys.). W sześciu krajach (Austria, Cypr, Finlandia, Norwegia, Szwajcaria i Szwecja) ponad 40\% populacji należy do różnych spółdzielni (dane statystyczne podaje za Piechowski, 2012; Cooperatives Europe, 2006, 2009). W poprzednim opracowaniu COGECA z 2010 r. podano liczbę 38 tys. spółdzielni. Zmiana spowodowana jest wyłączeniem z tej liczby francuskich CUMA (Les Coopératives d'Utilisation de Matériel Agricole, czyli małych spółdzielni użytkowania sprzętu rolniczego) oraz redukcją liczby spółdzielni w Grecji z uwagi na zmiany przepisów o rejestracji, a także konsolidacją spółdzielni (COGECA, 2010, 2014; W. Boguta, Z. Gumowski, K. Lachowski, 2007).
} 


\section{Spółdzielczość rolnicza we Francji}

We Francji działalność prowadzi łącznie ok. 2800 spółdzielni rolniczych (w tym spółdzielnie mleczarskie, winiarskie, owocowo-warzywne, pszczele, zwierząt hodowlanych czy spółdzielnie upraw rolnych i inne działające w rolnictwie bez CUMA) (COGECA, 2014); dodatkowo działają związki spółdzielcze, SICA ${ }^{3}$ oraz oddziały podmiotów spółdzielczych (French Ministry of Agriculture and Fisheries, 2005). Ich łączny obrót w 2004 r. wyniósł ponad 77 mld euro, by w 2014 r. osiagnąc ponad 84 mld euro [COGECA, 2014]. O dużej popularności tej formy prowadzenia działalności niech świadczy fakt, że dziewięciu spośród dziesięciu francuskich rolników to członkowie takich podmiotów. Stanowią one także istotne miejsce pracy dla ponad 165 tys. pracowników, przyczyniając się do wzrostu zatrudnienia na obszarach wiejskich i ich rozwoju (w $2004 \mathrm{r}$. dla 150 tys. pracowników) (https://www.lacooperationagricole.coop/nos-actualites-coopde-france).

Co więcej, od kilku lat obserwować można przejmowanie wielu ważnych przedsiębiorstw sektora rolno-spożywczego przez spółdzielnie i tworzenie oddziałów zajmujących się marketingiem oraz przetwórstwem. Rolnicy za pośrednictwem swoich spółdzielni i ich spółek zależnych kontrolują już ponad połowę przemysłu przetwórczego produktów rolnych we Francji (French Ministry of Agriculture and Fisheries, 2005). Wyodrębnić można różne rodzaje spółdzielni działających we Francji. Popularne są spółdzielnie podstawowe, które odbierają od rolników ich plony, często je przechowują, a potem - na jak najlepszych warunkach - wprowadzają na rynek. Niektóre spółdzielnie dysponują odpowiednimi budynkami i wyposażeniem pozwalającymi na magazynowanie. Działają także spółdzielnie zaopatrzenia, które kupują produkt, takie jak np. nasiona, opakowania, nawozy, pestycydy czy sprzęt rolniczy, by następnie sprzedać je swoim członkom. Odnotować należy spółdzielnie usług, których zadaniem jest zapewnianie członkom wszystkich usług niezbędnych do produkcji rolnej, np. konserwacji i naprawy sprzętu rolniczego bądź drobnych prac budowlanych. Niektóre spółdzielnie zajmują się przetwórstwem mleka, trzody chlewnej, wytwarzaniem pasz (French Ministry of Agriculture and Fisheries, 2005).

Wspomnieć należy także o CUMA, czyli małych podmiotach spółdzielczych zbiorowego użytkowania sprzętu rolniczego. Są one rodzajem spółdzielni usług. Dzięki odpowiedniemu wyposażeniu wykonują zadania, które mają bezpośredni wpływ na prowadzenie działalności rolniczej. Celem CUMA jest bowiem ułatwienie działalności lub poprawa i zwiększenie produktywności gospodarstw rolnych. Obecnie we Francji działa ponad 13 tys. CUMA z ponad 230 tys. członków. Według innych danych ponad 11,5 tys. (COGECA, 2014).

We Francji pierwsze przedspółdzielcze formy zrzeszania się pojawiły się już w na początku XII w., natomiast rozwój nowoczesnej spółdzielczości datuje się od początku XIX w. W tym państwie spółdzielnie traktowano początkowo jak spółki handlowe. Niemniej podejmowano działania zmierzające do stworzenia odrębnych regulacji dotyczących stowarzyszeń spółdzielczych. Przykładem są chociażby propozycje z 1849 r. czy 1866 r., a w ustawie z 24 lipca 1867 r. o spółkach4 na odrębne regulacje dotyczące stowarzyszeń spółdzielczych wskazuje już sama nazwa „spółki o zmiennym kapitale”

\footnotetext{
${ }^{3}$ Spółdzielnie rolnicze wspólnego interesu.

${ }^{4}$ Loi du 24 Juillet 1867 sur les societes, Bulletin officiel, no. 1513, no. 15328.
} 
(Bierzanek, 1984). W tym czasie działał też Philippe Buchez, uznawany za jednego z pierwszych francuskich teoretyków spółdzielczości, zwłaszcza produkcyjnej (chodziło np. o spółdzielnie robotnicze (Bruggemann, 1985).

We Francji współpraca producentów rolnych była odpowiedzią na rożnego rodzaju kryzysy doświadczające gospodarkę rolną od końca XIX w. Wskazać można dwa główne powody powstawania i rozwoju spółdzielni we Francji - odpowiadały one na takie potrzeby ekonomiczne członków spółdzielni, które nie mogły być zaspokajane przez nich samych, i dodatkowo broniły spółdzielców przed silną pozycją kupców na rynku (Chômel, 2010).

10 września 1947 r. uchwalono ustawę o statucie prawnym spółdzielni ${ }^{5}$ (Coutant, 1950). Łączyła ona $\mathrm{w}$ jednym akcie prawnym wszystkie zasady wspólne dla różnych rodzajów spółdzielni oraz określiła sposoby i warunki ich funkcjonowania. Warto tu nadmienić o zmianach wprowadzonych na mocy ustawy z 27 czerwca 1972 r., ustalających m.in. możliwość prowadzenia działalności gospodarczej z podmiotami niebędącymi członkami, odejście od zasady jeden członek - jeden głos, przeszacowanie ich kapitału, dopuszczenie inwestora do członkostwa w spółdzielni. Warto także wspomnieć o ustawach ze stycznia $1991 \mathrm{r}$. i lipca 1992 r., które dały inwestorom prawo do udziału w kapitale spółdzielni (Chômel, 2010).

We Francji, poza ogólną ustawą nr 47-1775 z 10 września 1947 r., istnieją także przepisy szczególne odnoszące się do wybranych branż spółdzielczości. Przykładowo sprawy spółdzielni rolniczych znalazły się w Code Rural (kodeksie rolnym, księga V, tytuł II), spółdzielni handlowców detalicznych - w kodeksie handlowym, spółdzielni pracowników produkcyjnych - w ustawie 78-763 z 19 lipca 1978 r., natomiast budownictwa spółdzielczego - w kodeksie budowlanym i mieszkaniowym (Chômel, 2010). W kolejnych latach odnotować należy zmiany Code Rural dotyczące spółdzielni rolniczych, które miały dostosować regulacje prawne do potrzeb społeczno-gospodarczych i przyczynić się do rozwoju spółdzielni.

Według francuskiej ustawy nr 47-1775 z 10 września 1947 r. po zmianie na podstawie ustawy nr 2014-856 z 31 lipca 2014 r. o społecznej i solidarnej ekonomii (gospodarki) ${ }^{6}$, spółdzielnia została zdefiniowana jako zrzeszenie (spółka) utworzone przez kilka osób łączących się dobrowolnie w celu zaspokajania swoich potrzeb gospodarczych (ekonomicznych) i społecznych, wykorzystujące własne, połączone środki. Realizuje ona swoje cele we wszystkich dziedzinach życia i pracy człowieka, przestrzegając następujących zasad: dobrowolnego i otwartego członkostwa dla wszystkich, demokratycznego zarządzania, współuczestnictwa ekonomicznego członków i ich szkolenia raz współpracy z innymi spółdzielniami. Z wyjątkiem klauzul specjalnych, odnoszących się do pewnych kategorii spółdzielni, każdy spółdzielca posiada jeden głos na walnym zgromadzeniu. Natomiast nadwyżki osiagane w spółdzielni są w pierwszym rzędzie przeznaczane na rozwój jej i spółdzielców. Ustawodawca francuski wprowadził zatem bezpośrednio do ustawy odwołanie do zasad spółdzielczych.

Główny cel spółdzielni stanowi zaspokajanie potrzeb gospodarczych (ekonomicznych) i społecznych spółdzielców. Jest to pojęcie bardzo szerokie i nawiązuje do definicji

${ }^{5}$ Loi n ${ }^{\circ}$ 47-1775 du 10 septembre 1947 portant statut de la coopération; JORF nº214 du 11 septembre 1947 p. 9088 ze zm; zwana ustawą nr 47-1775 z 10 września 1947 r.

${ }^{6}$ Loi n ${ }^{\circ}$ 2014-856 du 31 juillet 2014 relative à l'économie sociale et solidaire; JORF nº176 du 1 août 2014, p. 12666. 
spółdzielni europejskiej, która podaje, że jej celem jest zaspokojenie potrzeb członków, wsparcie ich gospodarczej oraz społecznej działalności. Odwołanie do obszernego pojęcia potrzeb członków prawdopodobnie wynika ze zróżnicowanej działalności spółdzielni we Francji. Popularne są tu spółdzielnie mieszkaniowe, rolnicze, pracy, konsumentów, ale także np. lekarzy czy transportowe (Chômel, 2010).

Szczegółowe unormowania dotyczące spółdzielni rolniczych francuski ustawodawca wprowadził do Code Rural. Te rozbudowane regulacje zawiera Tytuł II części L art. 521-1 do 528-1 (Gourlay, 1980), a także Tytuł II części R art. 521-1 do R 529-2. Zawarte w tych regulacjach zasady dotyczą: celów działalności spółdzielni rolniczych, wymagań odnoszących się do członków spółdzielni i podmiotów współpracujących, założenia spółdzielni, w tym zatwierdzenia przez Wysoką Radę Współpracy Rolnej (Haut Conseil de la Coopération Agricole), statutu, spraw finansowych, struktury organizacyjnej, w tym organów, zarządzania i kontroli, likwidacji, połączeń, podziału, a także częściowego przeniesienia aktywów.

Artykuł L 521-1 Code Rural wskazuje, że celem spółdzielni rolniczych jest wspólne stosowanie przez producentów rolnych wszystkich właściwych środków zmierzających do ułatwienia lub rozwoju ich działalności gospodarczej oraz poprawy bądź zwiększania wyników tej działalności. Natomiast według R 521-1 celem spółdzielni rolniczych, określonym w ich statutach, jest podejmowanie - niezależnie od sposobu i technik przez nie stosowanych - jednego lub więcej spośród następujących działań:

a) zapewnianie lub ułatwianie produkcji, sprzedaż, w szczególności na eksport, produktów rolnych i leśnych pochodzących z gospodarstw członków spółdzielni, bezpośrednio po ich zebraniu lub przechowywaniu, opakowaniu bądź przetworzeniu oraz poprawa produkcji, przechowywania, a także zarządzania jednym lub wieloma terenami leśnymi na rzecz członków spółdzielni;

b) zapewnianie i dostarczanie swoim spółdzielcom produktów, urządzeń, narzędzi i zwierząt niezbędnych do prowadzenia działalności bądź do utrzymywania nieruchomości leśnych, pod warunkiem, że przyczyniają się one do wytwarzania i przygotowywania niezbędnych produktów, w szczególności pasz dla zwierząt lub nawozów, oraz uczestniczenie w naprawie i konserwacji maszyn i narzędzi rolniczych;

c) oferowanie członkom spółdzielni na wyłączny użytek ich gospodarstw rolnych i leśnych wszystkich niezbędnych usług, zwłaszcza udostępnianie sprzętu, maszyn rolniczych, środków utrzymywania i naprawy, zwierząt, środków służących wprowadzaniu udoskonaleń technicznych i kształcenia zawodowego, wsparcie placówek badawczych, przeprowadzających eksperymenty i analizy, jak również odpowiednio wyspecjalizowanego personelu;

d) prowadzenie na rzecz członków spółdzielni działań i prac właściwych dla zawodów rolniczych.

Wymienione powyżej czynności mogą być również wykonywane przez spółdzielnie dla gospodarstw, które do nich należą lub które dzierżawią albo które zostały im przyznane. Co istotne, związki spółdzielni rolniczych mogą wykonywać takie same czynności jak spółdzielnie rolnicze (Chômel, 2013).

We Francji obowiązuje zasada swobody zakładania spółdzielni. Jednocześnie cechą charakterystyczną francuskiego modelu spółdzielczości jest terytorializm. Artykuł L 522-2 Code Rural stanowi, że tylko rolnicy, którzy mieszkają i prowadzą działalność rolniczą na określonym terenie, mogą założyć spółdzielnię. Zasada terytorializmu jest analizowana w literaturze francuskiej w kontekście wynikających z niej korzyści i wad (Filipp, 2013). 
W spółdzielniach funkcjonuje demokratyczny sposób zarządzania. $\mathrm{Na}$ walnym zgromadzeniu wszyscy członkowie co do zasady mają jeden głos, niezależnie od liczby udziałów i wielkości ekonomicznej transakcji ze spółdzielnią. Jednakże statut może wprowadzić pewne wyjątki. Niektórzy członkowie mogą mieć więcej głosów, zależnie od „jakości” ich uczestnictwa w działalności spółdzielni. Od 1973 r. obserwuje się proces włączania inwestorów w poczet członków spółdzielni, choć ograniczono ich wkład do mniej niż 50\% kapitału oraz do najwyżej 1/3 członków w radzie dyrektorów (Filipp, 2013).

Nie ulega wątpliwości, że do rozwoju spółdzielni rolniczych we Francji przyczynia się Wysoka Rada Współpracy Rolnej. Artykuł L 528-1 Code Rural wskazuje, że jest to instytucja użyteczności publicznej posiadająca osobowość prawną. Koordynuje ona realizację polityki publicznej w zakresie współpracy rolnej. Bada i proponuje strategiczne kierunki rozwoju sektora spółdzielczego. Czuwa nad jego stałym rozwojem, zgodnie z wymogami łączącymi efektywność ekonomiczną z zadaniami wynikającymi ze statusu spółdzielni oraz rozwojem terytorialnym. Jest ona gwarantem poszanowania reguł i zasad współpracy rolnej. Jej ciąła praca polega na prowadzeniu analiz i przedstawianiu propozycji m.in. w kwestiach prawnych i podatkowych. Wysoka Rada wprowadza i wycofuje spółdzielcze porozumienie ds. spółdzielni rolniczych i ich związków zgodnie z warunkami przewidzianymi w Code Rural (Suchoń, 2016).

\section{Spółdzielczość rolnicza w Niemczech}

Niemiecki rolnik jest $\mathrm{z}$ reguły członkiem co najmniej dwóch podstawowych spółdzielni rolniczych, które z kolei należą do spółdzielni regionalnych. Według danych statystycznych na koniec 2017 r. do regionalnych związków spółdzielczych związanych z rolnictwem (Genossenschaftsverbände) należały 2104 spółdzielnie (2186 spółdzielnie w 2016 r.), w tym 198 mleczarskich, 86 producentów bydła i mięsa, 162 plantatorów wina, 83 owoców i warzyw, 378 zakupu i sprzedaży produktów rolnych (zaopatrzenia i zbytu), 714 produkcji rolnej - oraz inne działające na wsi, np. kredytowe, związane z bioenergia, gorzelnictwem, leśnictwem. Ich łączny obrót w 2017 r. wyniósł ponad 63 mld euro (w 2016 r. 60 mld euro) (Deutscher Raiffeisenverband e.V., 2018a i b).

W systemie niemieckim występują także tzw. centrale spółdzielni, które działają wyłącznie w dziedzinie przetwórstwa, m.in. centrale spółdzielni mleczarskich (mleczarnie), ubojnie, spółdzielnie przetwórstwa owocowo-warzywnego oraz spółdzielnie winiarskie. Są to spółdzielnie, których członkami nie są producenci rolni, lecz spółdzielnie podstawowe, które składają się z rolników. Centrale uzupełniają i wspierają działalność miejscowych, podstawowych spółdzielni przetwórczych, gwarantując im konieczny zbyt wykraczający poza zasięg terytorialny spółdzielni oraz przejmując ważne mechanizmy i funkcje regulujące rynek i ceny (Helios, 2009; Suchoń, 2012).

Spółdzielnie podstawowe należą też do związków regionalnych oraz związku sprawdzającego (audyt). Te ostatnie są z kolei członkami Der Deutsche Raiffeisenverband e.V. (DRV), czyli niemieckiego związku spółdzielni Raiffeisen (Deutscher Raiffeisenverband e.V., 2011). Po II wojnie światowej, 18 listopada 1948 r. jego działalność została przywrócona w Wiesbaden na terenie Republiki Federalnej Niemiec. Jako stowarzyszenie spółdzielni branżowych reprezentuje interesy różnych spółdzielni wiejskich na poziomie krajowym i międzynarodowym, dlatego jego biura znajdują się w zarówno w Niemczech (Berlin, Bonn), jak i Brukseli. 
W części wschodniej Niemiec działają także rolnicze spółdzielnie produkcyjne (zwanej dawniej LPG). Prowadzą wspólne gospodarstwa na 27\% powierzchni gruntów rolnych landów wschodnich. Ich przychody w 2009 r. przekroczyły 1,8 mld euro. Jedna spółdzielnia produkcji rolnej ma przeciętnie około 1,8 tys. ha i 44 członków. Wynika $\mathrm{z}$ tego, że na jedną osobę przypada około 41 ha. Jako że tak niewielkie gospodarstwa rolne byłyby mało konkurencyjne na rynku niemieckim, a tym bardziej unijnym, członkowie spółdzielni nie wykazują, co do zasady, zainteresowania wycofaniem wkładów ze spółdzielni i założeniem gospodarstwa indywidualnego (Deutscher Raiffeisenverband e.V., 2010).

Spółdzielnie produkcji rolnej to podmioty prowadzące działalność rolniczą z wykorzystaniem coraz nowszych technologii, ochrony uprawy roślin i nawozów. Poza tym starają się one uwzględniać wymogi ochrony środowiska w rolnictwie. Spółdzielnie rolnicze prowadzą działalność w zakresie produkcji energii ze źródeł odnawialnych, energii wiatrowej, słonecznej i biogazu (Deutscher Raiffeisenverband e.V., 2010/2011).

W zachodniej części Niemiec długą historię mają natomiast spółdzielnie zajmujące się skupem i sprzedażą produktów wytwarzanych $\mathrm{w}$ gospodarstwie pojedynczego rolnika. Ugruntowaną pozycję na rynku mają także spółdzielnie mleczarskie. Przynależność do takich podmiotów to często tradycja wielopokoleniowa. Powstają także nowe podmioty. Niemcy są przykładem kraju, w którym występuje coraz większy wpływ spółdzielni na rynek energii. Działa tam ponad 940 spółdzielni energetycznych, a przedmiotem ich działalności jest produkcja i sprzedaż energii ze źródeł odnawialnych. W latach 2006-2014 utworzono 716 takich podmiotów (Deutscher Genossenschafts- und Raiffeisenverband e.V., 2014) z ponad 145 tys. spółdzielców (ok. 130 tys. to osoby prywatne, często mieszkańcy wsi i małych miasteczek). Członkami mogą być także podmioty publiczne. Wśród spółdzielni rolniczych są podmioty prowadzące biogazownie (których członkami są producenci rolni), wykorzystujące produkty rolne albo produkty uboczne z działalności rolniczej (Genossenschafts- und Raiffeisenverband e.V., 2014).

Powstanie niemieckiej spółdzielczości rolniczej bezsprzecznie łączy się z działalnością Hermanna Schulze-Delitzscha i Friedricha Wilhema Raiffeisena ${ }^{7}$ (Zinke, 1995). Pierwszym aktem prawnym regulującym te kwestie na ziemiach niemieckich była ustawa pruska z 27 marca 1867 r. o prywatnoprawnej pozycji spółdzielni gospodarczych i spółdzielni nabywczych ${ }^{8}$. Dzięki staraniom Schulze-Delitzscha ustawę tę ogłoszono 4 lipca 1868 r. jako północnoniemiecką ustawę federalną ${ }^{9}$, uwzględniającą zmiany i uzupełnienia (Helios, 2009). Po negocjacjach i dyskusjach, w maju 1889 r., w II Rzeszy uchwalono wreszcie Gesetz betreffend die Erwerbs- und Wirtschaftsgenossenschaften (GenG) vom 1. Mai 1889 ustawę o spółdzielniach gospodarczych i nabywczych ${ }^{10}$ (obecna nazwa Genossenschaftsgesetz, zwana dalej GenG). Oprócz zmian organizacyjnych, pozycji związków kontrolnych i łączenia się spółdzielni ten akt prawny w ogólnym kształcie obowiązuje do dnia dzisiejszego. Oczywiście odnotować należy kilka jego nowelizacji.

\footnotetext{
72018 r. w Niemczech obchodzony jest jako „200 Jahre Friedrich W. Raiffeisen“. Podaję za: https://raiffeisen2018.de/, pobrano 5 lipca 2018.

${ }_{8}$ Gesetz betreffend die privatrechtliche Stellung der Erwerbs- und Wirtschaftsgenossenschaften von 27.03.1867, GS S. 501.

${ }^{9}$ Gesetz betreffend die privatrechtliche Stellung der Erwerbs- und Wirtschaftsgenossenschaften von 4.7.1868, BGBI S. 415.

${ }^{10}$ BGB1. S. 369, 810; BGB1. 111 S. 4125-1.
} 
Całkiem odmienna sytuacja w zakresie prawodawstwa i rozwoju spółdzielczości miała miejsce w Niemieckiej Republice Demokratycznej. Po II wojnie światowej państwo to pod wpływem ZSRR musiało wprowadzać np. spółdzielnie produkcyjne. Początkowo w NRD obowiązywała ustawa o spółdzielniach z 1898 r. Dopiero po reformie Boden, w 1952 r. i wejściu w życie ustawy o rolniczych spółdzielniach produkcyjnych (LPG) - od 1959 r. na terenie NRD obowiązywała odmienna regulacja prawna. W następnych latach uchwalono kolejne akty prawne dotyczące rolniczych spółdzielni produkcyjnych, np. ustawę z 2 lipca 1982 r. $^{11}$ (Suchoń 2012).

Z dniem 3 października 1990 r. nastąpiło zjednoczenie Niemiec, niosące zmiany także w ramach rolnictwa, dlatego 29 czerwca 1990 r. uchwalona została ustawa W sprawie dopasowania rolnictwa ${ }^{12}$, stanowiąca podstawę przekształceń w mieniu wspomnianych spółdzielni LPG. W jej świetle każda spółdzielnia założona na podstawie socjalistycznego prawa dawnej NRD musiała przekształcić się w jedną z następujących form prawnych: spółdzielnię zarejestrowaną według ustawy z 1889 r. o spółdzielniach (obowiązującej na terenie RFN), spółkę osobową (prawa cywilnego, komandytową), spółkę kapitałową (spółkę akcyjną albo spółkę z ograniczoną odpowiedzialnością) (13 $^{13}$ (Steding, 1995). Po zjednoczeniu Niemiec kolejne nowelizacje przepisów poświęconych spółdzielniom obowiązują zarówno w starych, jak i nowych landach. Przede wszystkim należy podkreślić, że z dniem 18 sierpnia 2006 r. weszła w życie ustawa o wprowadzeniu spółki europejskiej oraz zmieniająca prawo spółdzielcze ${ }^{14}$, która miała dwojaki cel. Z jednej strony było nim stworzenie podstaw prawnych do implementacji spółdzielni europejskiej SCE jako nowej formy prawnej w prawie niemieckim. Z drugiej strony głównym założeniem nowych regulacji było wprowadzenie ułatwień przy tworzeniu i rejestrowaniu spółdzielni oraz pozyskiwaniu i utrzymywaniu dla niej kapitału/funduszy, jak również wzmocnienie praw członków. W literaturze niemieckiej podkreśla się, że ta tzw. duża reforma prawa spółdzielczego była oczekiwana od wielu lat (Münkner, 2010).

Do założenia spółdzielni wystarczy obecnie tylko trzech członków. Po podpisaniu statutu (musi mieć on formę pisemną) założyciele składają wniosek o rejestrację w sądzie (Steinle, Terbrack, 2009; Suchoń, 2012). Jednocześnie prawo przewiduje specjalną kontrolę procesu tworzenia i rejestracji przez związki sprawdzające (audyt). Łącznie z wnioskiem o rejestrację założyciele muszą przedstawić zaświadczenie związku regionalnego spółdzielni, że po zakończeniu procedury rejestracji będzie ona przyjęta do związku (§ 11ust. $2 \mathrm{nr} 3 \mathrm{GenG}$ ), jak również pisemną opinię związku o procesie tworzenia nowego podmiotu. Dopiero po rejestracji uzyskuje ona osobowość prawną i staje się zarejestrowaną spółdzielnią ${ }^{15}$. Jako osoba prawna ma swoje prawa i obowiązki; może nabywać własność i inne prawa rzeczowe; może być pozywana i pozywać inne podmioty.

\footnotetext{
${ }^{11}$ Gesetz über die landwirtschaftlichen Produktionsgenossenschaften vom 2. Juli 1982 (GB1. 1 Nr. 25, S.443).

${ }^{12}$ Landwirtschaftsanpassungsgesetz (GB1. I S. 642). Ustawa ta była wielokrotnie zmieniana.

13 Według danych statystycznych na 1790 dokonanych przekształceń 40 dawnych LPD wybrało spółkę akcyjną, 182 - spółkę komandytową, 306 - spółkę z ograniczoną odpowiedzialnością, a 1262 (ponad 70\%) spółdzielnię zarejestrowaną według ustawy z 1 kwietnia 1889 r. o spółdzielniach (Grimm,2004; Steding, 1995).

${ }^{14}$ Gesetz zur Einführung der Europäischen Genossenschaft und zur Änderung Genossenschaftsrechts, BGBl. I 2006, s. 1911-1957.

15 Sprawy związane z rejestracją spółdzielni uregulowane zostały w rozporządzeniu o rejestrze spółdzielni Verordnung über das Genossenschaftsregister (Genossenschaftsregisterverordnung - GenRegV), rozporządzenie o rejestrze spółdzielni, BGBl. I S. 2268.
} 
W rozumieniu przepisów niemieckiego prawa handlowego (Münkner, 2010; Suchoń, 2012) spółdzielnie są uważane za kupców (przedsiębiorców).

Wspominana już zmiana do GenG z 2006 r. wprowadziła możliwość przystąpienia do spółdzielni członków inwestujących. Są to podmioty niezainteresowane nawiązywaniem stosunków handlowych ze spółdzielnią, lecz wnoszące kapitał i oczekujące z tego tytułu dywidendy. Według art. 43 GenG każdy członek ma jeden głos. Statut może jednak przewidzieć prawo do kilku głosów. Przesłanki do tego powinny być określone w statucie i uwzględniać następujące kryteria: prawo do kilku głosów winno być zagwarantowane tylko tym członkom, którzy szczególnie wspierają działalność spółdzielni, a żadnemu z członków nie można przyznać więcej niż trzech głosów. Członkostwo w spółdzielni może być rozwiązane za wypowiedzeniem z zachowaniem odpowiedniego terminu. Zgodnie z $\$ 65$ GenG minimalny termin wynosi trzy miesiące przed końcem roku budżetowego, a maksymalny - pięć lat. Okres wypowiedzenia może być przedłużony do maksymalnie dziesięciu lat w spółdzielni, która składa się z przedsiębiorców. W przypadku, gdy okres wypowiedzenia wynosi dwa lata lub więcej członek ma dodatkowe prawo do wypowiedzenia członkostwa $\mathrm{z}$ powodów osobistych lub ekonomicznych. Ponadto członkostwo w spółdzielni wygasa, jeśli osobiste wymagania nie są spełnione przez członków spółdzielni ( $\$ 67 \mathrm{GenG}$ ), w przypadku śmierci członka ( 77 GenG) czy odmowy przyjęcia warunków kontynuacji członkostwa w wypadku połączenia. Przykładowo w świetle prawa niemieckiego członkostwo w spółdzielni może być rozwiązane za wypowiedzeniem z zachowaniem odpowiedniego terminu.

Jako że procesy globalizacji wymuszają konieczność łączenia spółdzielni, także temu zagadnieniu warto poświęcić trochę uwagi. Przez wiele lat kwestie te były uregulowane przede wszystkim w GenG ( $(93)$. Z dniem 1 stycznia 1995 r. weszła w życie ustawa z 1994 r. o przekształceniach (Umwandlungsgesetz, UmwG). Ten akt prawny ma zastosowanie nie tylko do spółdzielni, ale także innych podmiotów, m.in. spółki z o.o., spółki akcyjnej, spółki komandytowej w przypadku przekształceń w drodze połączenia czy podziału. W świetle tego aktu prawnego spółdzielnie mogą swobodnie łączyć się z innymi podmiotami gospodarczymi, w tym spółdzielniami, lub przekształcić np. w spółkę akcyjną.

Spółdzielnie jako przedsiębiorcy objęte są, co do zasady, takimi samymi regułami podatkowymi jak inne osoby prawne. Jeden z wyjątków dotyczy spółdzielni działających w rolnictwie i odnosi się do podatku korporacyjnego (dochodowego od korporacji - osób prawnych). Według $\S 5$ ust. 1 pkt 14 Körperschaftsteuergesetz ${ }^{16} \mathrm{z}$ podatku zwolnione sa: spółdzielnie nabywcze i gospodarcze, jak również związki (zrzeszenia), o ile ich działalność ogranicza się do:

a) wspólnego (zbiorowego) używania rolnych i leśnych pomieszczeń gospodarczych i przedmiotów;

b) świadczeń w ramach umów cywilnoprawnych dotyczących produkcji wyrobów rolnych i leśnych na potrzeby gospodarstw członków, jeśli świadczenia te są z obszaru leśnictwa bądź rolnictwa, do czego zaliczają się też świadczenia dotyczące budowy i eksploatacji urządzeń wentylacyjnych, dróg gruntowych (używanych przez pojazdy gospodarstwa rolnego lub leśnego) i melioracje;

\footnotetext{
${ }^{16}$ Körperschaftsteuergesetz (KStG) BGBl. I S. 4144 ze zm., Ustawa o podatku od osób prawnych.
} 
c) przetwarzania i wykorzystywania przez członków uzyskanych w swoich gospodarstwach rolnych wyrobów leśnych i rolnych, jeśli przetwarzanie (obróbka) i wykorzystywanie (użytkowanie) następuje w obszarze rolnictwa i leśnictwa; lub

d) doradztwa w zakresie produkcji i wykorzystywania wyrobów leśnych oraz rolnych pochodzących z gospodarstw członków spółdzielni.

Jednocześnie należy zaznaczyć, że wskazane zwolnienie podatkowe jest jednak wyłączone, jeżeli przychody spółdzielni (nabywcze i gospodarcze, jak również związków) z działalności nieokreślonych powyżej przekraczają 10\% wszystkich przychodów (Helios, 2009a; Suchoń, 2016).

\section{Podsumowanie}

Spółdzielnie działające w rolnictwie i na obszarach wiejskich oraz w innych obszarach gospodarki mają bogatą historię i ugruntowaną pozycję nie tylko w niemieckich $\mathrm{i}$ francuskich systemach prawnych, ale też $\mathrm{w}$ praktyce. Ustawodawcy $\mathrm{w}$ tych państwach starają się wprowadzić regulacje, które mają rozwiązywać problemy prawne istniejących podmiotów i zachęcić do zakładania nowych. Niewątpliwie duży wpływ na dalszy rozwój spółdzielczości w XXI w. mają: nowelizacja niemieckiej ustawy spółdzielczej (Genossenschaftsgesetz), która weszła w życie 18 sierpnia 2006 r., oraz francuska ustawa $\mathrm{nr}$ 47-1775 z 10 września $1947 \mathrm{r}^{17}$ po zmianie na podstawie aktu prawnego $\mathrm{nr}$ 2014-856 z 31 lipca 2014 r. o społecznej i solidarnej ekonomii (gospodarki), a także Code Rural. Znaczącą rolę odgrywają także aktywnie działające organizacje spółdzielcze, takie jak Deutscher Raiffeisenverband e.V. w Niemczech, Coop de France we Francji, które podejmują działania mające chronić interesy spółdzielni rolników na szczeblu krajowym, jak i unijnym.

Polski prawodawca, tworząc nowy model spółdzielczości, powinien bezsprzecznie skorzystać z doświadczeń i niektórych rozwiązań występujących w Niemczech i Francji. $\mathrm{Na}$ uwagę zasługuje szeroka francuska definicja spółdzielni rolniczych zawarta w Code Rural i szczegółowe przepisy dotyczące ich założenia oraz funkcjonowania. W systemie niemieckim wystarczą obecnie tylko trzy osoby fizyczne lub prawne, żeby powołać spółdzielnię. Inne ciekawe rozwiązanie to możliwości przystąpienia do spółdzielni członków inwestorów, kontynuacja członkostwa przez spadkobierców, zasady wypowiadania członkostwa (w tym wprowadzenia dłuższego okresu pozwalającego na wystąpienie ze spółdzielni), odstępstwa od zasady jeden członek jeden głos. Nowatorskie są niektóre regulacje związane $\mathrm{z}$ walnym zgromadzeniem, np. podejmowanie decyzji przez członków także na drodze elektronicznej albo możliwość uczestniczenia członków rady nadzorczej w walnym zgromadzeniu poprzez transmisję wideo lub audio. Na uwage zasługuje także odrębna ustawa o przekształceniach (Umwandlungsgesetz) z 1994 r., której odpowiednika nie ma $\mathrm{w}$ systemie polskim. Ten akt prawny ma zastosowanie nie tylko w odniesieniu do spółdzielni, ale także innych podmiotów m.in. spółki z o.o., spółki akcyjnej, spółki komandytowej w przypadku przekształceń w drodze połączenia czy podziału.

\footnotetext{
${ }^{17}$ Loi n ${ }^{\circ}$ 47-1775 du 10 septembre 1947 portant statut de la coopération; JORF n0214 du 11 septembre 1947, p. 9088 ze zm.
} 
Prócz uproszczeń oraz nowości wprowadzonych w ostatnich latach dotyczących spraw organizacyjnych, systemy niemiecki i francuski przewidują także inne instrumenty. To właśnie przepisy finansowe, $w$ tym podatkowe, stanowią jeden $\mathrm{z}$ efektywnych czynników zachęcających do wyboru formy spółdzielni oraz przekształcania spółek w spółdzielnie, łączenia spółdzielni i nabywania udziałów spółkach kapitałowych. Preferencje podatkowe obejmujące także spółdzielnie zajmujące się przetwórstwem czy doradztwem przyczyniają się do rozwoju struktury spółdzielczości. Co istotne, ulga ta zachęca do współpracy pomiędzy spółdzielniami zarówno wertykalnej (pionowej), jak i horyzontalnej (poziomej). Takie współdziałanie nie powoduje utraty ulg podatkowych w Niemczech.

$\mathrm{Na}$ koniec warto dodać, że $\mathrm{w}$ sektorze rolnym $\mathrm{z}$ uwagi na sytuację na rynkach europejskim i światowym, procesy globalizacji i instrumenty Wspólnej Polityki Rolnej następować będzie dalszy proces konsolidacji spółdzielni. Zmniejszanie się liczby producentów rolnych oznacza mniejszą liczbę członków. Jednak istotne są obroty spółdzielni, a one z reguły wzrastają. Świadczy to z kolei o rozwoju spółdzielni i rolników będących jej członkami. Odnotować należy także powstawanie nowych podmiotów w zakresie np. energii odnawialnej, szczególnie w Niemczech.

\section{Literatura}

Asschhoff, G., Hennigsen, E. (1995). Das deutsche Genossenschaftswessen. Entwicklung, Struktur, wirtchaftliches Potential. Fritz Knapp. Frankfurt.

Bierzanek, R. (1984). Prawo spółdzielcze w zarysie (Co-operative law in outline). PWN. Warszawa.

Boguta, W., Gumowski, Z, Lachowski, K. (2007). Organizacja mazowieckiego rynku rolnego poprzez tworzenie grup producentów rolnych na bazie prawa spółdzielczego (Organization of the Mazovian agricultural market by creating groups of agricultural producers based on cooperative law), pr. zb. Wyd. KRS. Warszawa.

Bruggemann, F.M. (1985). Genossenschaften in Frankreich. Die Rechtsstellung von Agrargenossenschaften und Credit Agricole. Münster.

Chômel, C. (2004). The long march of the European Cooperative Society, RECMA - Revue Internationale de l'Économie Sociale, Hors-Série, no. 291, 1-5.

Chômel, C. (2010). France w: Study on the implementation of the Regulation 1435/2003 on the Statute for European Cooperative Society (SCE), Part II. National Report. Bruksela, 519-545.

Chômel, C. (2013). Le cadre juridique et la gouvernance descoopératives agricoles, w: C. Chomel, F. Declerck, M. Filippi, R. Mauget, O. Frey, Les coopératives agricoles. Identité, gouvernance et stratégies. Primento Digital Publishing. Paris.

Chômel, C., Declerck, F., Filippi, M., Mauget, R., Frey, O. (2013). Les coopératives agricoles Identité, gouvernance et stratégies. Primento Digital Publishing. Paris.

Code rural et de la pêche maritime, (2012). red. H. Bosse-Platière, LexisNexis, Paris.

COGECA (2010). Agricultural Cooperatives in Europe, Main Issues and Trends. Brussels.

COGECA (2014). Development of Agricultural Cooperatives in the EU. Brussels, 6-10.

Cooperatives Europe (2006). Performance Report. Key Figures 2005, Brussels.

Cooperatives Europe (2009). 2009 European Co-operatives Key Statistics, Cooperatives Europe Asbl. Brussels.

Coutant, L. (1950). L'Evolution du droit cooperatif de ses origines à 1950: La double tendance vers son unification et son autonomie, la loi du 10 sept. 1947, la codification en cours. Matot-Braine. Reims.

Deutscher Genossenschafts- und Raiffeisenverband e.V. (2014). Energiegenossenschaften, Ergebnisse der Umfrage des DGRV und seiner Mitgliedsverbände, Frühjahr 2014. Pobrane 28 sierpnia 2018 z: http://www.raiffeisen.de/downloads/publikationen/.

Deutscher Raiffeisenverband e.V. (2007). Agrargenossenschaften sind ein Eckpfeiler des ländlichen Raums in Ostdeutschland. Pobrane 5 września 2012 z: http://www.raiffeisen.de.

Deutscher Raiffeisenverband e.V. (2010). Wir leben Nachhaltigkeit! 20 Jahre Agrargenossenschaften eine Erfolgsgeschichte; Genossenschaften - gestern, heute, morgen. Pobrane 4 sierpnia 2018 z: http://www.raiffeisen.de/downloads/publikationen/. 
Deutscher Raiffeisenverband e.V. (2010/2011). DRV-Bericht über den Geschäftsbetrieb der Agrargenossenschaften 2010/2011 Pobrane 5 września 2012 z: http://www.raiffeisen.de/downloads/publikationen/.

Deutscher Raiffeisenverband e.V. (2011). Ausblick 2011, Geschäftsbericht 2010. Pobrane 5 września 2012 z: http://www.raiffeisen.de/downloads/publikationen.

Deutscher Raiffeisenverband e.V. (2014). Aktueller Geschäftsbericht, Rückblick 2013 - Ausblick 2014, 11 i 64.

Deutscher Raiffeisenverband e.V. (2018a). Raiffeisen Statistischer Bericht 2017. Pobrane 28 sierpnia 2018 z: https://www.raiffeisen.de/wp-content/uploads/downloads/2017/09/Statistischer-Bericht-2017.pdf.

Deutscher Raiffeisenverband e.V. (2018b). Entwicklung der Raiffeisen-Organisation 1950-2017. Pobrane 28 sierpnia 2018 z: https://www.raiffeisen.de/sites/default/files/Dekadenblatt_Juni_2018.pdf.

Filipp, M. (2013). L'ancrage territorial des entreprises coopératives agricoles et le développement durable, w: C. Chômel, F., Declerck, M., Filippi, R., Mauget, O., Frey (2013), Les coopératives agricoles. Identité, gouvernance et stratégies. Primento Digital Publishing. Paris.

French Ministry of Agriculture and Fisheries Edited (2005). Agricultural Cooperation in France. Paris. Wersje uaktualniona i przetłumaczona z j. francuskiego na j. angielski przez Coop de France, lipiec 2005.

Gourlay, P.G. (1980). Coopératives agricoles, Dalloz. Paris.

Grimm, C. (2004). Agrarrecht, C.H. Beck. München.

Helios, M. (2009a). Ertragsbesteuerung der Genossenschaft und ihrer Mitglider w: Beck'sches Handbuch der Genossenschaft, red. M. Helios, Th. Strieder. Wyd. Beck. München.

Helios, M. (2009b). Rechtsgeschichtliche Entwicklung des Genossenschaftswesens w: Beck'sches Handbuch der Genossenschaft, red. M. Helios, Th. Strieder. Wyd. Beck. München.

Münkner, H. (2010). Germany, w: Study on the implementation of the Regulation 1435/2003 on the Statute for European Cooperative Society (SCE). Part II. National Report. Bruksela.

Nast, A. (1928). Code de la cooperation. Paris.

Piechowski, A. (2012). Spółdzielczość w Unii Europejskiej w: Rola i przyszłość spółdzielczości: gospodarka konkurencyjnej Polski (Cooperatives in the European Union in: The role and future of cooperatives: competitive economy of Poland). Kancelaria Prezydenta Rzeczypospolitej Polskiej, Biuletyn Forum Debaty Publicznej nr 19.

Staab, J. (2013). Erneuerbare Energien in Kommunen. Energiegenossenschaften gründen, führen und beraten, Springer Gabler. Wiesbaden.

Steding, R. (1994). Produktivgenossenschaften in der ostdeutschen Landwirtschaft - Ursprung und Anspruch, Inst. für Genossenschaftswesen Berlin.

Steding, R. (1995). Die Produktivgenossenschaften im deutschen Genossenschaftsrecht: eine Studie zur Genese und Exegese des § 1 Abs. 1 Ziff. 4 GenG, Vandenhoeck \& Ruprecht Göttingen.

Steding, R., Böhme, K. (2004). Die Produktivgenossenschaft im Agrar- und Gewerbebereich. Streitpunkt in der Genossenschaftswissenschaft w: Grundfragen der Theorie und Praxis der Genossenschaften, red. R. Steding, $\mathrm{H}$. Blisse, M. Hanisch, Inst. für Genossenschaftswesen Berlin.

Steinle, E., Terbrack, C. (2009). Gründung der Genossenschaft und Genossenschaftsregister, w: Beck'sches Handbuch der Genossenschaft, red. M. Helios, Th. Strieder, Wyd. Beck. München.

Suchoń, A. (2012). Spółdzielczość rolnicza w Niemczech, (Agricultural cooperatives in Germany), Przeglad Prawa Rolnego, 1, 239-266.

Suchoń, A. (2012). Wpływ Wspólnej Polityki Rolnej na rozwój spółdzielczości rolniczej (Impact of the Common Agricultural Policy on the Development of Agricultural Cooperatives). Zeszyty Naukowe Polityki Europejskie, Finanse i Marketing, 8, 438-452.

Suchoń, A. (2016). Prawna koncepcja spółdzielni rolniczych (Legal concept of agricultural cooperatives). Wyd. UAM. Poznań 2016.

Welling, H. (1966). Die Beteiligung der eingetragenen Genossenschaft an anderen Gesellschaften nach geltendem und künftigem Recht. Diss. Münster.

Zinke, J. (1999). Die Entwicklung der landwirtschaftlichen Genossenschaften in der Weimarer Republik, | Institut für Genossenschaftswesen. Berlin.

Do cytowania / For citation:

Suchoń A. (2018). Spółdzielczość rolnicza we Francji i Niemczech - wybrane zagadnienia prawne i ekonomiczne. Problemy Rolnictwa Światowego, 18(4), 451-462; DOI: 10.22630/PRS.2018.18.4.133

Suchoń A. (2018). Agricultural Cooperatives in France and Germany - Selected Legal and Economic Issues (in Polish). Problems of World Agriculture, 18(4), 451-462;

DOI: 10.22630/PRS.2018.18.4.133 